\title{
Enhancing Agricultural Productivity through Crops Management
}

\author{
Esther Wahaga* \\ Research Scientist, CSIR-Food Research Institute, Accra, Ghana \\ *Corresponding Author: Esther Wahaga, Research Scientist, CSIR-Food Research Institute, Accra, Ghana.
}

Received: April 23, 2019; Published: July 01, 2019

DOI: 10.31080/ASAG.2019.03.0552

Agriculture is the backbone of many economies of the World and huge efforts and funds have been channelled to its development in terms of crop improvement, insect pest control, soil fertility improvement and water resource management. Managing agricultural crops involves making and implementing decisions on crops to maximize yield and for that matter profit. This involves making and implementing decisions regarding water, soils, seed, weeds, fertilizer, insects and disease and post-harvest strategies. However, these may defer depending on the geographical location, educational, cultural setting and psychological makeup of the people managing the crops. These may also vary between smallholder and large-scale farmers.

Agricultural crop productivity has pushed research and indigenous farmers to think of better and alternative ways of managing crops to achieve better yield. Research has also shown that high yielding varieties when transferred to farmers are transferred along-side best management practices in terms of when to plant, how to plant, how to scout for insect pest and diseases, on what soils to plant, what crop, when to plant and post-harvest management practices. Farmers cherry pick which agricultural practice to adopt. Some of these best practices are wholly adopted by farmers while others are partially adopted together with indigenous crop management practices. The conscious blend of these management practices has in several ways helped both large-scale and small-scale farmer achieve efficiency in crop management. However, there is very little extension services in some parts of the World, especially in developing countries like Ghana, where there is currently, a ban on public sector employment by the International Monetary Fund (IMF). The consequence of the ban is the non-replacement of retiring extension staff rendering the farmer extension ratio nothing to write home about. In the end the remaining extension staff do not visit and interact with farmers like they did before, negatively impacting on the transfer of innovative crop management strategies to farmers.

The high literacy rate among farmers in most developing countries also negatively affect the ability of farmers to keep farm records to manage agricultural crops. Nevertheless, technology has help to improve farm management. The use of mobile phones by farmers has made it possible for farmers to communicate their problems and ideas to colleague farmers far and near. The use of WhatsApp has even made it much more interesting as farmers are able to share pictures of their problems and successes. In recent times there are spontaneous and efficient IT solution that farmers use to manage activities on a farm by gathering, linking, reporting and predicting data on crop management where income and agricultural activities are programmed and monitored. Some Mobile Applications also enable farmers to remotely monitor crops for useful information to make decisions by observing the efficiency of crops and acting promptly to reduce cost and enhance productivity.

Research has shown that large farms produce more efficiently than small farms since they enjoy economies of large scale by ordering in large volumes directly from wholesalers thereby cutting down on cost. Technological advancement has seen largescale farmers make better decisions in managing their crops. Through access to efficient IT solutions, high yielding varieties, pest and disease resistant and drought resistant varieties, better land preparation, planting, fertilizer application, weeding, harvesting and post-harvest techniques has seen large scale-farmer manage crops more efficiently.

Land tenure system also greatly affects crop management in both developed and developing countries. In most developing countries it is of enormous concern to women farmers as it adversely affects their ability to acquire fertile land. Land tenure issues may also affect agricultural crop management in that, land tenure arrangements may affect crop rotation.

In conclusion, physical conditions, social, cultural and available technologies therefore allow a wide range of options in farming systems that aids the management of agricultural crops.

\section{Volume 3 Issue 8 August 2019 \\ (C) All rights are reserved by Esther Wahaga.}

